Document downloaded from:

http://hdl.handle.net/10251/100727

This paper must be cited as:

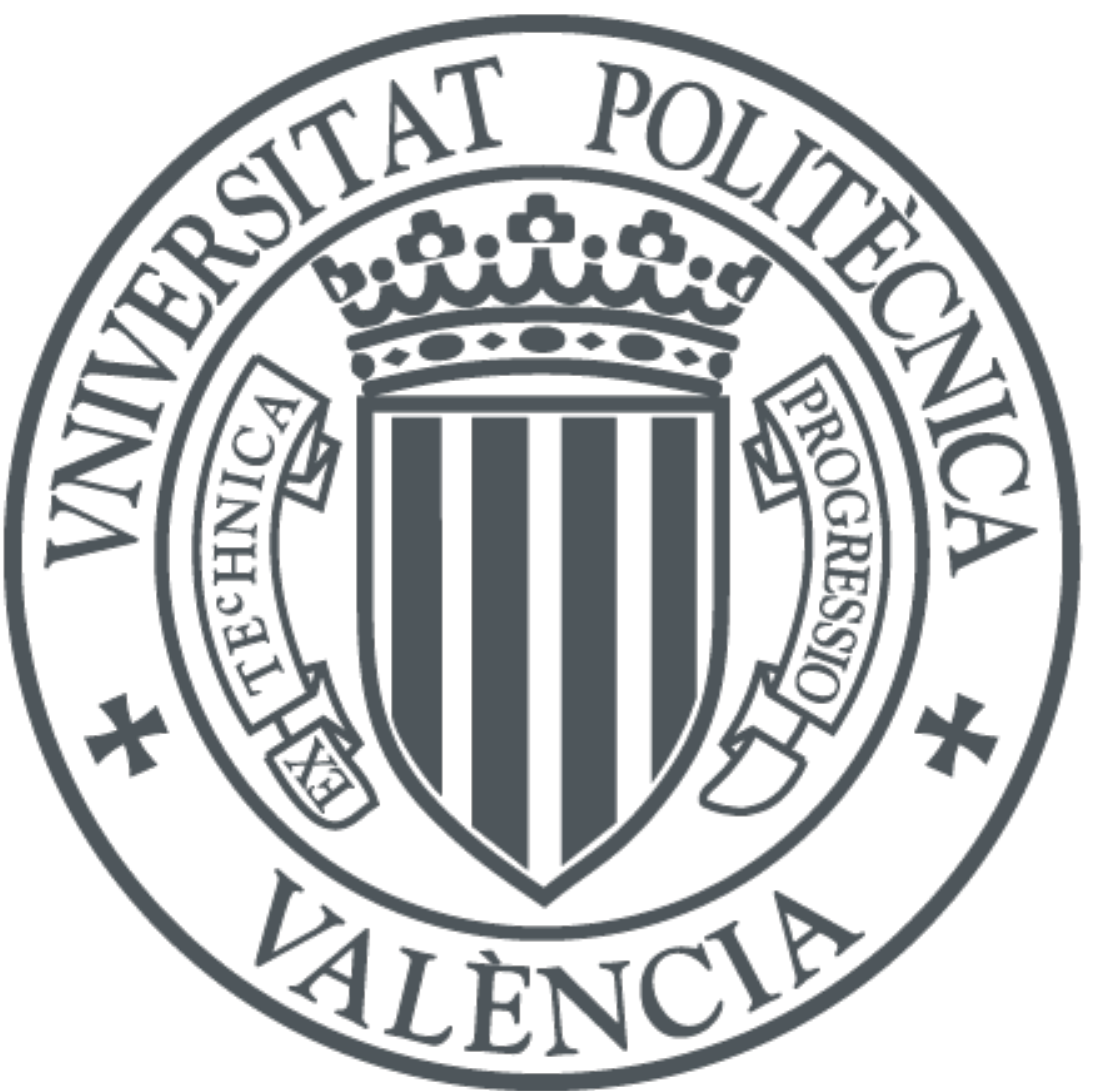

The final publication is available at

https://doi.org/10.2352/J.ImagingSci.Technol.12.56.5.050402

Copyright Society for Imaging Science \& Technology

Additional Information 


\title{
Technical Evolution of Ceramic Tile Printing
}

Authors: Sanz, V.; Reig, Y.; Feliu, C.; Bautista, Y.; Ribes, C.; Edwards, M.

Source: Journal of Imaging Science and Technology, Volume 56, Number 5, September 2012 , pp. 50402-1-50402-7(7)

Publisher: $\underline{\text { Society for Imaging Science and Technology }}$

\begin{abstract}
Ceramic tile decorating techniques have evolved significantly in recent years. Digital inkjet printing technology has enabled digital systems to be used for the direct decoration of ceramic tiles, revolutionizing ceramic tile decoration and providing many advantages over traditional decoration techniques. It was the formulation of inks with soluble and vitrifiable stains that allowed inkjet printing technology to be introduced into ceramic tile decoration. The incorporation of milled inorganic pigments into the inks broadened the available color palette. However, the colloidal instability of these inks and the constraints of the printing heads themselves made it necessary to reduce pigment particle size, thus limiting color saturation and the color gamut. In order to increase color saturation and obtain a set of pigmented inks with colors more closely resembling CMYK colors, pigments with larger particle sizes need to be used. Indeed, other digital decorating techniques, such as xerography, allow larger particle sizes to be used, while also providing the advantages associated with digital decoration. However, the implementation of this technique for ceramic tile decoration requires the development of appropriate ceramic toners and adaptation of printing machines. This article reviews the technical evolution of ceramic tile printing and describes the development of a prototype, based on xerographic printing, that is able to print ceramic tiles directly and provides greater color intensity and a wider color gamut.
\end{abstract}

Document Type: Research article

DOI: $\underline{\text { http://dx.doi.org/10.2352/J.ImagingSci.Technol.12.56.5.050402 }}$

Publication date: 2012-09-01 


\section{Introduction}

This paper provides a case study of an innovation that emerged in the Castellon region in the first decade of 2000: that is, Ink-jet Printing (IJP) technology. This technology has been described as part of a 'digital revolution in the ceramic industry' (Hutchings, 2009; Giacomini, 2010). The Castellon region concentrates over 90\% of Spanish ceramic tile production (Escardino, 2001; Tortajada et al., 2008). Over the years, various printing techniques have been used to decorate tiles. Traditional contact printing methods include screen printing, flexography and rotogravure (De Carlo and Montani, 2003; Berto, 2007). Several authors point to innovations in ceramic tile decoration enabled by the introduction of IJP technology is opening new opportunities in the ceramic industry and other economic sectors (Hutchings, 2009; Moreno et al., 2010; Sanz et al., 2011). This study analyses the generation and development of the IJP innovation from the perspective of ID, LRIS and learning regions (Becattini, 1990; Storper, 1993, 1997; Florida, 1995; Asheim, 1996, 2007; Sforzi, 2006). Specifically, we apply an evolutionary theoretical lens to technological change in relation to the following dimensions: 1. absorption of new knowledge (including exploration and acquisition of available knowledge); 2. generation of new knowledge, technology and innovation; and, 3. diffusion of innovation throughout the regional 'learning system' (Caniëls and Romijn, 2003; Iammarino, 2005; Iammarino and McCann, 2006; Herrschel, 2010). Our main research questions are related to:

- the agents involved in IJP technology generation;

- the generation, appropriation and diffusion of IJP technology.

\section{Methodology}


We adopt a qualitative approach and a case study methodology, in which the technological innovation (IJP) produced by the CCDIS is the unit of analysis. A case study is a history of a past or current phenomenon, that draws on multiple sources of information and evidence. It is a powerful instrument that captures the complex dynamic of the innovation process (Eisenhardt, 1989; George and Bennett, 2005). We describe the innovation process and the events and relationships leading to the emergence of the IJP technology. They are constituted by a series of interdependencies and a wide range of actors and temporary or informal relationships, which are difficult to capture. This allows us to take account of how a phenomenon is influenced by its context and to gather data from a variety of sources. Specifically, we considered patents, scientific articles, and secondary documents such as organization reports and technical articles from the literature (Web of Science, Scopus, Ceramic abstracts, etc.) and the information in patent databases (Esp@cenet, la Oficina Española de Patentes y Marcas (OEPM, Spain); PAJ and the Derwent Innovation Index) using the Matheo Patent software (Breschi and Lissoni, 2004). We consulted the annual reports of Gold Alfa's Award of the Spanish Society of Ceramics and Glass (2010), which is a prestigious annual award that has been presented at the CEVISAMA Fair since 1975 in recognition of the most important innovations in the sector. To obtain an in-depth understanding of the sector we conducted 21 interviews during January to July 2011, with the principal actors involved in the generation, development and diffusion of the IJP technology using an hermeneutic-dialectic method where the interviewer played an active role, and interviewer and respondent shaped the interview 'content' together (Jørgensen and Phillips, 2002). The selection of items was based on feedback from a panel of experts and a some pilot questionnaires. 


\section{Origins, development and diffusion of the IJP technological innovation}

IJP technology refers to a variety of techniques used to generate droplets of ink which are propelled towards a predetermined surface. They include several IJP techniques such as continuous (binary, multi-level, greyscale), drop-on-demand (DOD)/valve jet (shutter, array) and impulse jet (activated and chevron), among others (Wijshoff, 2008; Garnsey et al., 2010). The IJP industry emerged in the 1970si', disrupted the dominant design of dot matrix desktop printing in the late 1980s, entered a growth phase in 1990 related to office computer system applications, and reached maturation at the end of the 1990s (Hutchings, 2009; Garnsey et al., 2010). When development was transferred to the industrial field, various issues emerged that made complicated technology transfer and development (Sanz et al., 2011). The first studies of IJP technology applied to fine ceramic decoration were conducted in 1980 by W. Roberts of British Ceram Research Ltd (UK). For some 10 years research focused on the adaptation and upgrading of ink properties, particularly flowability and conductivity, and testing of different printing methods and substrates. Developments in IJP technology as a new method of decoration on an industrial level appeared in 1997 in the Castellon region. To explore the history of this technology we ran database searches using some general keywords, such as inkjet, ceramic, tile, etc., identifying documents related only to ceramic tile manufacture and rejecting applications for the design and manufacture of printed circuit boards, ceramic processing tools and fine ceramics, etc. (e.g. a patent registered in 1975 mentions the IJP technology in reporting a procedure for flexographic printing). Analysis of patents shows that finding appropriate inks was critical for the development of the IJP technology in the ceramics industry because ceramic inks have certain particularities 
and properties. Their most important characteristics are: (a) high levels of stability and precipitation; agglomeration and changes in viscosity can clog the injectors (about $50 \mu \mathrm{m})$; (b) strong tints, such that small amounts can cause problems in the substrate (770pL), may decrease the intensity of the colours achieved and result in poor quality decoration (surface tension, drying rate of the drop); (c) neutral $\mathrm{pH}$ required to prevent corrosion of the heads, (chemical compatibility between nozzle and the ink). Information obtained from the interviews shows the non-linearity of the innovation process, and the level of secrecy and competition among firms in the search for an appropriate ink.

The first IJP machine prototype for the ceramic tile industry was introduced in 2000; its inventors received the Gold Alfa Award of thepanish Society of Ceramics and Glass. The period 2000-2005 saw the development of several prototypes and the first commercialization and diffusion of the technology in the ceramic sector. The first industrial IJP machine was developed by José VicenteTomás Claramonte (JVTC), owner of a small supplier company dedicated to computer engineering for ceramics in Villarreal, a town with a long tradition of ceramic tile manufacture in the CCDIS. He bought a print-head and conducted printing tests with Rafael Vicent Albert (RVA), an engineer working in the firm, and Antonio Querol, a chemical engineer who was working in the R\&D department of Ferro Enamel Española S.A., a subsidiary of the Spanish multinational Ferro Corporation.

\subsection{First stage: exploration and absorption of knowledge}

Several technicians and engineers working in different firms were keen to introduce this technology, but the complexity, and the high cost of the research related to raw 
materials and inks required to adapt printheads for use on an industrial scale, made this new technology unpopular. The developers attended to the Drupa Fair, the world's biggest printing equipment exhibition in the world, held every four years in Messe Düsseldorf in Germany. This milestone in the development of IJP technology corresponds to the phase of 'sequence of problems' and 'auto-catalysm of knowledge' related to resolution of an initial problem (Coombs et al., 2003). There were five firms, four in the CCDIS and one in France, that were attempting to adapt printheads and solve the problems related to the inks.

The literature shows that radical innovations and innovations with a high degree of originality and 'radicalness' face more obstacles to acceptance by industry (ExpósitoLanga and Molina-Morales, 2010). During the first trials with printheads, JVTC presented his ideas for developing ink jet printing to a number of companies in the sector, but none of them considered the development feasible. He and his friend travelled to the Cambridge ink jet cluster and presented their ideas to the then CEO of Cambridge Consultants Ltd., which is linked to the Xaar Group ${ }^{i i}$ from which they acquired their first printhead. However, the Xaar Group also was not interested. In contrast to the findings in the literature (Morales and Martínez-Fernández, 2004; Expósito-Langa and Molina-Morales (2010) the innovation in our case came from a small firm with no relationships with local research institutions that might have acted as information suppliers.

\subsection{Second stage: new knowledge generation}

Our interviewees confirmed that the main constraint was inks. It implied a paradigm shift in chemistry and research on nanoinks and nanopigments. After several months of 
experimenting with hundreds of pigments through trial and error, JVTC and his partners were able to demonstrate the viability of the inks R\&D to Ferro Enamel Española SA, a subsidiary of Ferro Corp. in Castellón. Ferro’s long (92 years) experience as a leading global supplier of technology-based materials for a broad range of manufacturers, and its well established R\&D activity, provided the necessary knowledge and experience in inks. The reciprocity and strong trust among the three developers were a key element, they set up a company called KERAjet to conduct R\&D to develop electronics, software and inks (Ferro, 2001). Thus Ferro Enamel Española SA, attracted by local opportunities, acted as a 'learning interface’ (Belussi and Asheim, 2010). It also was an intermediary between Enginyeria PC and and Seiko, a printheads supplier from Japan. It was the first machinery innovation that broke with the tradition in Europe of machinery innovations originating in Italy. Confidence, cooperation and secrecy were crucial in this stage of the IJP development. KERAjet worked with two printheads developed by external firms: Xaar (UK) and Seiko (Japan). Xaar printheads, which are used for high quality printing, do not have to run at such high speeds on line and do not involve very dark colours; Seiko's printheads are used for high quality printing in multiple colours, for high speed glazing lines and for very deep-coloured tile production. On 14 October 1998 JVTC applied for a patent at the Spanish patent office and on 27th September 2000 sent an application to the European Patent Office. The patent was for a device comprising at least two independent print modules easily replaceable with a single-pass mechanism, where only one pass is needed to complete the decorative motif (Tomás Claramonte, 1999, p. 2). This characteristic allows considerably faster printing speed (with a print quality of 200dpi). The first IJP prototype had 20 print heads with a printing width of up to $700 \mathrm{~mm}$ and images up to $1.365 \mathrm{~cm}$ wide at speeds of $50 \mathrm{~m} / \mathrm{min}$. Two of the machine's inventors said that the multiple printheads and the single-pass 
method distinguished it from other technological solutions which mostly used single head systems. A major problem in this first development was achieving yellow and brown colours, which are in high demand from the ceramic sector. In 2001, Ferro Corp. patented a 'New yellow ink for the decoration of ceramics and glass using inkjet technology' (Querol Villalba and Guaita Delgado, 2002). Between 2000 and 2003 various competitors in the CCDIS made unsuccessful attempts to deploy the IJP technology using soluble inks using DOD (drop on demand) and CIJ (continuous ink jet) methods. In 2004, Ferro introduced the INKCID® system based on pigment inks. Table 1 presents the principal technological and scientific knowledge contributions in the form of patents and scientific articles, related to the development of IJP technology.

Table 1. IJP devices and machines patented for decorating in ceramic tile industry (In colour grey the Spanish contribution)

\begin{tabular}{|c|c|c|c|}
\hline Titular & Inventors & Tittle/description & Priority date \\
\hline $\begin{array}{l}\text { Tomas Claramonte, J. } \\
\text { V. }\end{array}$ & $\begin{array}{l}\text { Tomas } \\
\text { Claramonte, J.V. }\end{array}$ & $\begin{array}{l}\text { Dispositivo para decoración de baldosas cerámicas } \\
\text { (Translation: Device for decorating ceramic tiles) }\end{array}$ & 14/10/1998 \\
\hline $\begin{array}{l}\text { Hegedus G; Kocsis A; } \\
\text { Florian G. }\end{array}$ & $\begin{array}{l}\text { Hegedus G; } \\
\text { Kocsis A; Florian } \\
\text { G. }\end{array}$ & Liquid Dispensing Apparatus & 09/03/1998 \\
\hline $\begin{array}{l}\text { SACMI } \\
\text { COOPERATIVA } \\
\text { MECCANI }\end{array}$ & $\begin{array}{l}\text { Ricci Claudio; } \\
\text { Acerbi Pierugo }\end{array}$ & Method and device for decorating ceramic tiles & 08/09/2004 \\
\hline System Spa & Stefani Franco & An apparatus for decorating ceramic products & $07 / 02 / 2006$ \\
\hline KERAJET S A & $\begin{array}{l}\text { Tomas } \\
\text { Claramonte, J.; } \\
\text { Vicent Abella, } \\
\text { Rafael; } \\
\text { Gasso Arcas, } \\
\text { Pedro }\end{array}$ & $\begin{array}{l}\text { Modulo autónomo de impresión por chorro de tinta } \\
\text { (Translation: Inkjet printing autonomous device ) }\end{array}$ & 28/11/2006 \\
\hline $\begin{array}{l}\text { GRUPPO BARBIERI } \\
\text { \& TAROZZI }\end{array}$ & Tarozzi Fausto & $\begin{array}{l}\text { Decoration method and system for decorating ceramic } \\
\text { products }\end{array}$ & $17 / 04 / 2007$ \\
\hline $\begin{array}{l}\text { XENNIA } \\
\text { TECHNOLOGY } \\
\text { LTD }\end{array}$ & $\begin{array}{l}\text { Yeong Kay K ; } \\
\text { Hirt Thomas }\end{array}$ & $\begin{array}{l}\text { Method, printing device, and formulations for } \\
\text { decorating glass or ceramic items }\end{array}$ & $19 / 02 / 2007$ \\
\hline CRETA PRINT, S.L. & $\begin{array}{l}\text { Blasco Claret, } \\
\text { Victor }\end{array}$ & $\begin{array}{l}\text { Sistema de impresión en azulejos cerámicos } \\
\text { (Translation: Printing system for ceramic tiles) }\end{array}$ & 06/06/2008 \\
\hline $\begin{array}{l}\text { MACCARI } \\
\text { ANTONIO }\end{array}$ & Maccari Antonio & $\begin{array}{l}\text { Plant and method for decoration by means of ink-jet } \\
\text { technology }\end{array}$ & 08/11/2006 \\
\hline ARGON HT SRL & $\begin{array}{l}\text { Manoukian } \\
\text { Harutiun }\end{array}$ & Screen printing machine having a replaceable IJP unit & $04 / 06 / 2002$ \\
\hline KERAJET SA & $\begin{array}{l}\text { Tomas } \\
\text { Claramonte, J.; } \\
\text { Vicent Abella, } \\
\text { Rafael; }\end{array}$ & $\begin{array}{l}\text { Sistema de mantenimiento de máquinas de impresión } \\
\text { por chorro de tinta, de gran formato } \\
\text { (Translation: Maintenance system for ink-jet printing } \\
\text { machines for large formats) }\end{array}$ & 09/02/2009 \\
\hline
\end{tabular}


Technological diffusion is the process by which innovations - whether new products, new processes or new management methods - spread within and across economies. There are two stylized facts related to technological diffusion: spread - the S-curve when diffusion rates gradually rise and then fall over time. There is a period of relatively rapid adoption sandwiched between an early period of slow take up and a late period of slow progress to satiation); and economic and social factors. Economic and social factors influence individual decisions to begin using the new technology based on the costs and benefits of its adoption. The benefits of IJP technology compared with previous decorating techniques, such as gravure printing and flat screen-printing technologies, were undisputed. However, its diffusion in the ceramic sector was not as rapid as expected. There were problems related to the stability and low chromatic intensity of the inks for application in an industrial process. These aspects and the high price of materials ( $\mathrm{Ru}, \mathrm{Au})$ acted as barriers to the rapid expansion of IJP technology in the CCDIS. KERAjet SA intensified its research efforts on colour range and intensity and ink and enamel stability in order to obtain acceptable colours. IJP technology began to spread in the ceramic sector after the appearance of a new option on the market in 2005. Torrecid, a multinational frit, glaze and ceramic producer, launched a range of pigment inks in collaboration with Durst Phototechnik AG, a company devoted to image processing, and Fujifilm Dimatix (Spectra), a printhead manufacturer (Sanz et al., 2012). Information from interviews show that a range of different strategies was employed. These included experimenting with equipment developed by companies with experience in design and engineering of coupling printheads already on the market (KERAjet JETTABLE in Israel), collaborations and joint marketing strategies involving a manufacturer of frits, glazes and ceramic colours and a specialist in digital printing machines (TORRECID and DURST, using binary Fujifilm Dimatix heads), and a 
manufacturer of machines for ceramic decoration and a specialist in digital printing machines (CretaPrint and the Italian firm TENOITALIA with Xennia). In 2012, there are at least 13 different machines available in the market and the most widely used printheads are piezoelectric provided by Xaar, Spectra and Seiko. The first Tecnargilia Design Award in 2010 to celebrate the latest technological innovation in this sector was for digital decoration. Tecnargilia is the most important international fair for technological and stylistic innovations for the ceramics industry. Figures 6 and 7 depict the progressive adoption of IJP technology. It shows the number of companies that have manufactured machines since 2000 and the number of machines installed in April 2010 (N=373 machines) (Giacomini, 2010). The number of machines in April 2011 was 664, $48.6 \%$ of which are Spanish in origin and 31\% are Italian.

From 2000 to 2008, with the exception of JETTABLE which developed its own inks, tile firms were supplied exclusively by KERAjet-Ferro and Torrecid-Durst. This probably slowed the introduction of IJP technology in the sector. In 2009, KERAjetFerro and Torrecid-Durst began to supply inks from other certified sources. KERAjet developed a certification protocol for testing and control of ink quality and currently has a presence in several major ceramics centres in Spain, Italy, Portugal, China, and other countries. Through continuing investment in knowledge and accumulated competences the firm has produced several generations of machines. In Spain, and particularly in the CCDIS and the construction industry on which it depends, the economic downturn has had a major effect on tile manufacture. However, in 2010 KERAJet SA had 200 machines installed and functioning across the world, which is evidence of the success of IJP technology in the ceramics field.

The role of the ITC in the diffusion process is interesting. According to Molina-Morales et al. (2002) the ITC acts as an intermediary bridging to external knowledge and new 
technologies and supports exploration and exploitation activity. Our case study shows that the ITC did not participate in the exploration and R\&D stages, but played a key role in the diffusion of and improvement to IJP technology.

\section{Conclusion and final comments}

This paper investigated an innovation process in a Spanish region introducing an analytical framework -the DIS approach- that combines theoretical perspectives of RIS, IDs and Innovation Systems. We describe the introduction and progress of the IJP technology, that can be described not as a radical innovation but as a very 'relevant innovation' related to ceramic decoration that is revitalizing the ceramic sector. We analyze this innovation from the evolutionary point of view including the processes, interactions and feedback involved in its generation, development and evolution.

Our in-depth case study showed that the IJP technology emerged as a result of local dynamic interactions in the CCDIS and also it represented a break in the pattern of ceramic machinery innovations originating in Italy. Our case study confirms findings from research on ID related to heterogeneity in the ceramic district (Molina-Morales and Martínez-Fernández, 2009a), informal relationships related to cooperation and information exchanges underpinned by mutual trust and face-to-face contacts and the role of in-house $R \& D$ in the innovation process, particularly due to the frit, glaze and colour providers (Albors, 2002; Tortajada et al., 2008; Gabaldón et al., 2009). One of the most remarkable aspects is the importance of external ties and relationships with agents outside the Castellon region, aspects that are generally neglected by mainstream

studies of ID. The CCDIS can be characterized as an 'open learning system' where the act of building external linkages and complementing internal knowledge with external knowledge (e.g. with the Cambridge 'district', the external suppliers Xaar and Seiko, 
the Drupa fair, etc.) was crucial for innovation performance in the case of the IJP technology development.

The venture team -an entrepreneur of a small firm and their friends, one of them from a multinational subsidiary- participated in an evolving process of exploration and absorption of external knowledge from other industry sectors. This collaboration was based on a common culture of trust and mutual reinforcing capabilities and provided informational and other benefits related to access, timing and referrals, in a competitive environment. In this sense this research illustrated that teams with greater strategic consensus can harvest greater benefits from appropriately structured external networks. Most of the knowledge was tacit and rooted in practice in the frit subsector. It was related to know-how (procedural knowledge rather than declarative knowledge) and the long experience of skilled workers in whom the knowledge was 'embedded' and influenced by social ties, friendship, trust, reputation, solidarity, norms, habits and coevolved rules of conduct. Trust relations are assumed to reduce inter-firm transaction costs and to complement managerial and technological capabilities, and encompass a complex process of interrelationships of endogenous (knowledge feedback) and exogenous (knowledge inputs) mechanisms in the learning district system. Secrecy and patenting played a key role in the sharing of knowledge, and the search for exploitation opportunities and an innovation strategy.

In contrast to the findings in the literature, our case study shows that research institutions (the ITC and universities) did not act as an intermediate agent in the early exploration and R\&D stages (Molina-Morales et al., 2002). We attribute this feature to the degree of radicalness of the IJP innovation. However, the ITC and other research institutions participated in the diffusion of and improvements to IJP technology through collaborative R\&D projects with IMPIVA and CDTI. 
This paper contributes by providing empirical evidence for a better understanding of the complex and systemic characteristics of the innovation dynamics beyond the traditional economic perspectives of 'industrial clustering' and ID. This approach could be complemented by and extended with further studies.

\section{Acknowledgements}

This work was supported by ITC)-AICE and the Quevedo Program of the Spanish Ministry of Science and Innovation Education and Culture through Project no. PB970804, and by the Agencia Española de Cooperación Internacional through Project RedINNOVA

\section{References}

Barba, A. (2005), 'From Chemical Engineering to ceramic technology: A review of research at the Instituto de Tecnología Cerámica’, Boletín de la Sociedad Española de Cerámica y Vidrio, 44(3), 155-160.

Berto A. M. (2007), 'Ceramic tiles: above and beyond traditional applications', J. European Ceram. Soc., 27,1607-1613.

Boix, R. (2009), 'The empìrical relevance of industrial districts in Spain'. In Becattini, G.; Bellandi, M. and De Propis, L. (Eds.). A Handbook of Industrial Districts. Edward Elgar Pub., UK, USA. Chap. 26, 343-359.

Boix, R. and Galletto, V. (2006), 'Sistemas locales de trabajo y distritos industriales marshallianos en España’. Economía Industrial, 359,165-184.

Braunerhjelm, P. and Feldman, M. (2006), Cluster genesis. Technology-based industrial development. Oxford. Oxford University Press.

Cantner, U.; Meder, A. and Ter Wal, A. L. J. (2010), 'Innovator networks and regional knowledge base', Technovation 30, 496-507.

Cohen, W. M. and Levinthal, D. A. (1990), 'Absorptive Capacity: A New Perspective on Learning and Innovation’, Admin. Sci. Quart., 35 (1),128-152.

Clymer, N. and Asaba, S. (2008), 'A new approach for understanding dominant design: the case of the ink-jet printer', Journal of Engineering Technology Management, 25, 137-156.

Cooke, P. (1996), 'Reinventing the region: firms, clusters and networks in economic development'. In Daniels \& Lever (Eds.), The global economy in Transition. Essex:Longman. 
Davenport, H. and Prusak, L. (2000), Working Knowledge. Harvard Business School Press.

De Carlo, A. \& Montani, M. (2003), 'The digital revolution in tile decoration', Ceramic World Review, 51,78-84.

Doloreux, D. (2002), 'What we should know about regional systems of innovation', Technology in Society, 24(3), 243-263.

Dosi, G. (1982), 'Technological paradigm and technological trajectories', Research Policy, 11(3), 147-162.

Escardino, A. (2001), 'La innovación tecnológica en la industria cerámica de Castellón', Boletín de la Sociedad Española de Cerámica y Vidrio, 40(1), 43-51.

FERRO Italia. (2001), 'Tile Decoration moves into the 21st century, a Digital Revolution: The story of Kerajet Technology', International Ceramics Journal. Product Technology.

Garnsey, E.; Stam, E. and Thomas, B. (2010),'The emergence and development of the Cambridge ink jet printing industry'. In Fornahl, D.; Henn, S. and Menzel, M. P. (Eds.). Emerging clusters. Theoretical, empirical and political perspectives on the initial stage of cluster evolution. Edward Elgar Pub., UK, USA., 265-291.

Gordon, I. and Mccann, P. (2000), 'Industrial clusters: complexes, agglomeration and/or social networks?’, Urban studies, 37, 513-532.

Herrschel, T. (2010), 'Growth and Innovation of Competitive Regions: The Role of Internal and External Connections', European Planning Studies, 18(7), 1169-1172.

Hutchings, I.M. (2009), 'Ink-jet printing in micro-manufacturing: opportunities and limitations'. In Proc. 4M/ICOMM Int. Conf. on Multi-material Micro Manufacture, Cardiff University: Karlsruhe, Germany.

Lorenzen, M. (2005), 'Why do clusters change?' European Urban and Regional Studies, 12(3), 203-208.

Lundvall, B. A. (1992), National Systems of Innovation: towards a theory of innovation and interactive learning. London: Pinter.

Molina-Morales, F. X. (2002), 'Industrial districts and innovation: the case of the Spanish ceramic tiles industry', Entrepreneurship and Regional Development, 14(4), 317-335.

Moreno, A.; Lázaro, V.; Mateu, A. and Reig, Y. (2010), 'Innovations and new trends in ceramic tile decoration', Advances in Science and Technology, 68, 165-175.

Mothe, J. De La and Paquet, G. (Eds.) (1998), Local and Regional Systems of Innovation. USA: Kluwer Academic Publishers.

Motoyama, Y. (2008), 'What Was New About the Cluster Theory?: What Could It Answer and What Could It Not Answer?', Economic Development Quarterly, 22,353363.

Moulaert, F. and Sekia, F. (2003), 'Territorial innovation models: a critical survey', Regional Studies, 37, 289-302.

Sanz, V.; Ribes, C.; Bautista, Y.; Feliu, C. and Reig-Otero, Y. (2011), 'Technical evolution of Ceramic Tile Digital Decoration'. NIP27. 27th International Conference on Digital Printing Technologies. Society for Imaging Science and Technology. October 26, 2011, Minneapolis, Minnesota, 532-536. 
Seong-Jim K.; Mckean, D.E., (1998), 'Aqueous TiO2 suspension preparation and novel application of ink-jet printing technique for ceramics patterning', Journal of materials science letters, 17, 141-144.

Sociedad Española de Cerámica y Vidrio (2010), 'Innovación y desarrollo del azulejo en las tres últimas décadas: colección de los premios Alfa de Oro 1977-2009’. Madrid.

Storper, M. (1993), 'Regional 'Worlds' of Production: Learning and Innovation in the Technology Districts of France, Italy and the USA', Regional Studies, 27(5), 433-455.

Tomás Claramonte, J. V. (1999), 'Dispositivo para decorar baldosas cerámicas'. Patent $\mathrm{N}^{\circ}$ EP99949020.4.

Tortajada Esparza, E.; Fernández de Lucio, I. \& Gabaldón Estevan, D. (2008). 'Competitiveness and Profitability? New Challenges in the Ceramic Frit, Glaze and Colour Industry’, Tile \& Brick International. Manual 2008:59-65.

Vonortas, N. S. (2009), 'Innovation networks in industry'. In Malerba, F. \& Vonortas, N. S. (Eds.). Innovation networks in industries. Edward Elgar Pub. UK, USA, 27-44.

Wijshoff, H. (2008), Sructure and fluid-dynamics in piezo inkjet printheads. Herman Wijshoff. Venlo, The Netherlands.

Ybarra, J. A. (1991), 'Industrial districts and the Valencian Community. New industrial organisation programme'. Discussion Papers DP/44 (Geneva: International Institute for Labour Studies).

Zirulia, L. (2009), 'The dynamics of networks and the evolution of industries: a survey of empirical literature'. In Malerba, F. \& Vonortas, N. S. (Eds.). (2009). Innovation networks in industries. Edward Elgar Pub. UK, USA., 45-77.

\footnotetext{
i Piezoelectric ink-jet (PIJ) printers are based on three patents from the 1970s. The first patent was taken out by Zoltan and the Clevite Company in 1972 (US Patent 3,683,212), the second belongs to Stemme of Chalmers University dated 1973 (US Patent 3,747,120) and the third is owned by Kyser and Sears from the Silonics Company registered in 1976 (US Patent 3,946,398) (Wijshoff, 2008). In 2005 M.A. Gröninger, M.J. van den Berg, and H.M.A. Wijshoff patented an 'Inkjet system, method of making this system and use of said system' (US Patent 20050285908).

ii Xaar Group plc spun-off in 1990 from CCL (Cambridge Consultants Ltd, a technological design consultancy, spunoff from the University of Cambridge). At the start of the 1970s CCL was working on various continuous ink jet printing technologies funded by the chemical multinational ICL. CCL was contracted to develop ink jet technologies for printing textiles at high speed, over large widths and in colour. Xennia was founded in 1996 by Alan Hudd, exDomino ink and R\&D group leader, who saw an opportunity in industrial ink jet from DOD techniques that were being developed. Xennia has specific expertise in 'difficult' materials in IJP printing, such as inorganic materials e.g. metals, phosphors, pigments, biomedical fluids, structural scaffold materials, conductive inks and materials for displays (Clymer and Asaba, 2008; Garnsey et al., 2010).
} 